\section{石垣島におけるタマナヤガの発生消長と 季節的移動の可能性について}

\author{
杉本 渥*2 . 小林 尚** \\ * 熱带農業研究センター沖繩支所 \\ ** 東北農業試験場
}

(1977 年 9 月 8 日 受領)

近年，東北地方で発芽直後の造成牧草地にタマナヤガ幼虫に よる大被害が生じた事例が多くあった。本種は北陸〜東北地方 では越冬できず (千葉·長谷川，1972；松浦·宮下，1977），遠 隔地から飛来する成虫が 発生源だとする考え方が発表されてい る (小林, 1969; 小林, 1972; 布施, 1975; OKU et al., 1975; 千葉，1976)。インドや北アフリカ〜ヨーロッパでも，本種が 春には北へ，秋には南へ長距離移動することが推測されてい る (Woodhouse and Fletcher, 1912; KAPUR, 1955; RAINEY, 1967; CAYRol, 1972; NovÁk, and SPITZER 1972)。筆者らは石垣島における本種の発生消長を調査し, あわ せて本種が日本付近の亜熱带地域においても季節的な移動をし うる可能性があるかどうかを検討してみた。その概要をここに 報告する。

本文にさきだち，貴重なご教示を賜った東北咷業試駘場 奥 俊夫博士, 沖繩県農林水産部農産課 諸見里安勝氏,ならびに気 象資料の調査にご便宜を舓った石垣島地方気像台の方々に厚く お礼を申し上げる。

調 査方 法

石垣市真栄里の熱带農業研究センター沖繩支所構内に. $20 \mathrm{~W} フ ゙$ ラックライト乾式トラップを設置し，1973 年 4 月〜1975 年 5 月 にタマナヤガ成虫の誘殺数を調べるとともに, 誘殺雌の腹部を 解剖して卵巣発育程度を調査した。また，1973 年6月，8月， 10 月と 1974 年 4 月, 6 月, 8 月に島内各地の野菜畑户耕起後 1 か月内外で若い雑草が 生えている耕地からネキリムシを採集 し，これを室内飼育して得た成虫の種名を同定すると上もに， 産卵前期間を調べた。

\section{結果および考察}

調査結果と調査期間中の風向，気温を㴬 1 図に示した。

\section{年間発生消長}

成虫の誘殺は秋から冬〜春にはほぼ連続して見られたが，夏 （6〜8月）にはほとんどとだえた。幼虫の生息も春と秋には認
められたが，6月には少数または皆無となり，8月には全く見 られなかった。カブラヤガ幼虫との混生率が秋に京く，春には 低下寸る傾向が見られ，特に 1973 年 6 月にはタマナヤガ幼虫は 姿を消してしまった。この結果から，本種は石垣島では秋から 冬を越して春までは継続的に生息するが，初夏に幼虫生息密度 が急に低下し，夏には極端に少なくなるか，あるいは生息しな くなると考えられる。

沖繩本島でも，琉球農業試験場コザ支場における 1968〜1971 年の予察灯調査記録によれば，本種成虫の誘殺は $1 \sim 7$ 月と 10 〜11 月に見られ, 中でも $3 \sim 5$ 月に多く, また，幼虫による被 害は 4 月と 10 月に多い（諸見里の私信による)。このことや前 記インドや北アフリカの例から，本種が夏にほとんど 生息を見 なくなる現象は，石垣島に限らず，西熱帯地域（沖繩·台湾· 中国大陸中南部などを含む）の低地に共通のものと考えられる。

\section{誘殺䧳成虫の卵紧発育状態の季節的変化}

石坦島に打ける誘殺雌の 卵巣発育個体率は秋〜冬〜早春にか けては高かったが，4月末〜 5 月末には低下した。これに対し て, 東北地方では本種成虫の誘殺は, $4 \sim 6$ 月から 9 月〜10月 上旬にかけて連続的に見られるが，卵巣発育個体率の低下は 7 月中旬以降に見られ（千葉，1972），特に 8 月中旬以降洁誘殺此 の全てが未発育個体となる(小林ら，1974）。

長距離移動を行なう種々の昆虫では, 移動するのは卵巣未成 熟の成虫である場合が多いことが知られている（JOHNSON, 1969)。本種は卵巣発育速度が日長の違いによって变化し, 幼虫 期を 13 時間以上の長日条件下で経過すると，産卵前期間が短日 条件の場合よりも約 2 倍長く 6 日内外となり，成虫は長距離 移動に適した生理的形質を備えるといわれる（千葉・長谷川, 1971； 千葉，1972)。

東北地方では本種が越冬しないことと， 3 月末〜 9 月中旬は 上記長日条件（常用薄明時間を含む）下にあり，定住型成虫が 生ずる短日条件にはないことからすると，千葉 (1972) が考察し たように，7 月中旬以降に誘殺される卵巣未発育の 此成虫は長 日条件下で育った移動型であり, 卵巣発育個体法他地域から飛 来したものである可能性が考えられる。

石垣島で同じ長日条件が得られる期間は 4 月上旬〜 9 月上旬 であるが，本種の卵〜羽化の期間が $20^{\circ} \mathrm{C}$ では 50 日内外であ ることから（長谷川·千葉，1969），4月末〜 5 月に出現する成 出の一部は, 上記の長日条件下で䏍ってはいないと推測される。 掉実，老令幼虫を野外から採集し，外気に近い温度条件で飼育 して得た成虫の産卵前期間は, 1974 年 4 月下旬に得たものでは $3 \sim 4$ 日 (平均 3.8 日) と短く, 1973 年 11 月のそれの $2 \sim 4$ 日（平均 3.3 日）と大差なかった。しかし，4月末〜 5 月に誘

1 On Seasonal Prevalence and Possibility of Seasonal Migration of the Black Cutworm, Agrotis ipsilon (Hufn.) on Ishigaki Is., Okinawa. By Atsushi Sugimoto (Okinawa Branch, Tropical Agriculture Research Center, Ishigaki, Okinawa 907-01) and Takashi KoвAYASHI (Tohoku National Agricultural Experiment Station, Shimokuriyagawa, Morioka 020-01) 日本応用動物昆虫学会誌 (応動昆) 第 22 巻 第

2 現在 熱帯農業研究センター 

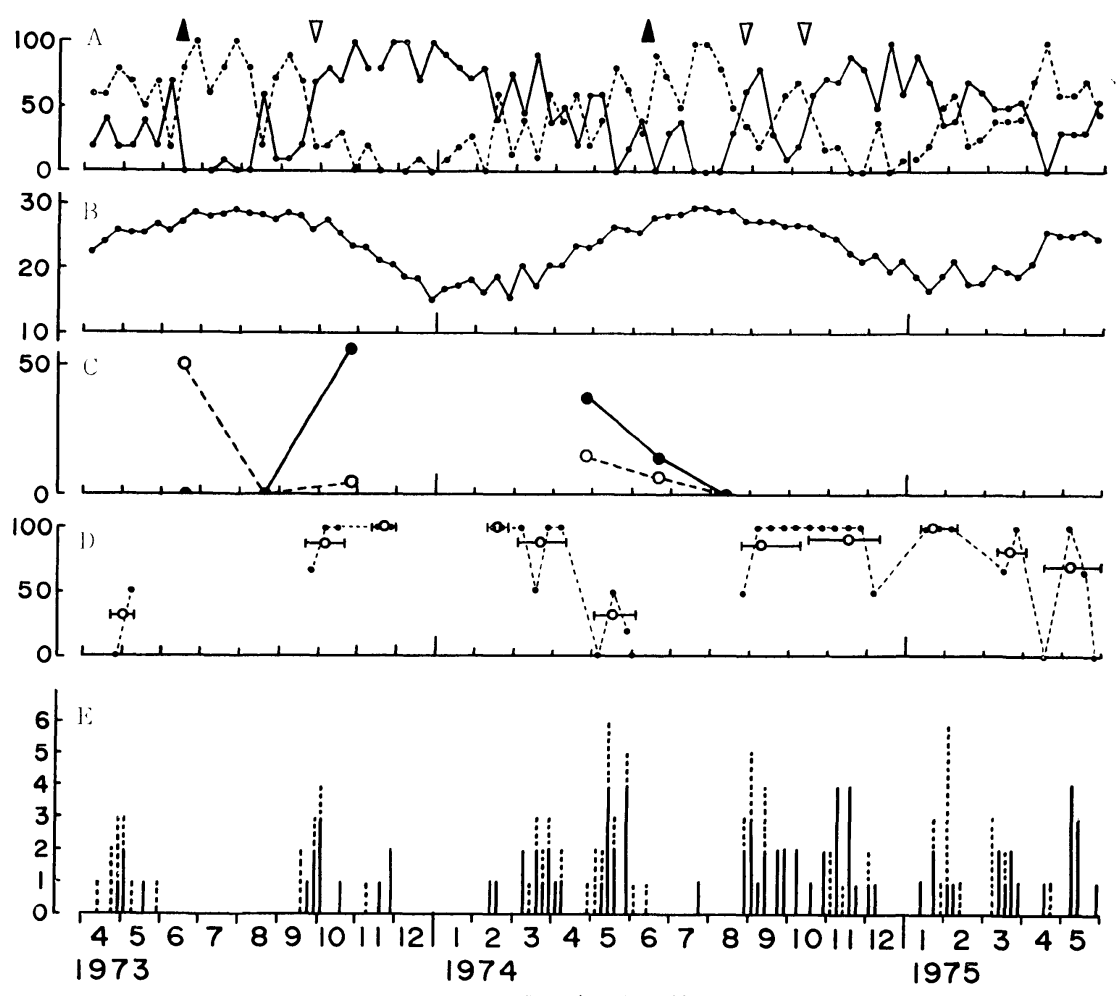

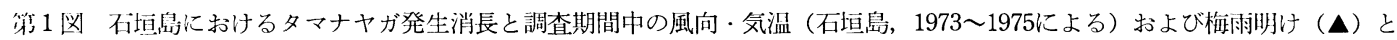
寒気団南下 $(\nabla)$ の時期 (天気困日記, 1974，1975による).

A : 北寄り（一, 東北東〜北〜西北西）および南寄り（……東南東〜南〜西南西）の風（日最大風速時）の句別出現 率 \%. B : 旬平均気温 ${ }^{\circ} \mathrm{C} . \mathrm{C}$ ：老令幼虫の採集数，○はカブラヤガ．D：ブラックライト誘殺此成虫の卵巣発育個体 率 \%, は旬平均, ○は誘殺波平均. E : 半旬別成虫誘殺数, 一—は雌, ……雄.

殺された雌成虫の卵巣発育個体率は確かに低かった。誘殺雌の 卵巣発育個体率の低下は, 東北地方では夏から秋に, 石坦島で は春から初夏に見られるが，いずれも，その地における発生終 息前の時期に相当する。しかも，不垣島でのそれは東北地方に おける誘殺初期に，また東北地方のそれは石垣島における秋の 誘殺再開期とほぼ一致する。このことだけからすると，本種は 亜熱带と, 夏季に生息可能な温带地域との間を季節的に移動す るのではないかという推測もできそうに思える。

布施 (1977) は 4 6月に山形県庄内地方へ飛来する本種は, 主として北緯 25〜30 あたりの中国大陸を飛び立ったものであ ると考えており，筆者らもこの説に同意しているが，両地域の 間には日本本土西南部のような温帯の温暖地域があり, そこに 本種の越冬または越夏の可能な地や常発地があるとすれば，そ こと巠熱帯または冷凉地との間での移動の可能性も考えなけれ ばなるまい。徳島では 4 月〜10 月 (尾崎, 1975), 福阔では 4 月 〜11月（滰口, 1960）に4〜5世代が䜑められ, 鹿児島では幼虫 の越冬 (堀切の私信による) が諗められるという。しかし，こ れらの地帯での成虫の季節的移動を説明するのに十分な資料は,
まだほとんど得られていない。

\section{発生・移動と気象条件との関係}

日本付近では夏には南寄り，冬には北寄りの季節風が吹き， 春 ·秋はその交代期となる（倉嶋，1972）。なお, 春から夏に出 現率を増す南寄りの季節風は，次の 2 段階に区別される。すな わち, 第 1 段階は「春一番」で始まり初夏に最盛期に達する日 本海, 中国東北区, 沿海州, 北海道方面を通る強い温帯低気圧 に吹きこむ風であり, 第 2 段階は盛夏に太平洋の亜熱帯高気圧 から吹きこむ風である（倉嶋，1972）。

第 1 図に示した風の出現率のグラフにも，上記のとおりの季 節風の交代が見られ，てれと成虫誘殺状沉との間には次のよう な関係が認められる。すなわち，石垣島では 6 月半ばごろに梅 雨が明け, 南風が卓越する盛夏に入るが, 誘殺はそれ以前に終 息する。しかし， 8 月末〜 9 月半ばには卓越風が北に転じ，そ れと同時に誘殺が再開される。なお，盛夏には平均気温 $29^{\circ} \mathrm{C}$ 内外の槀温が続く(第 1 図)。本種は休服性がなく (千葉・長谷 川, 1971; 松浦·宮下, 1977), しかも亜熱帯地域では約 $30^{\circ} \mathrm{C}$ 以上の高温となる夏には生息できないといわれている（WILLI- 


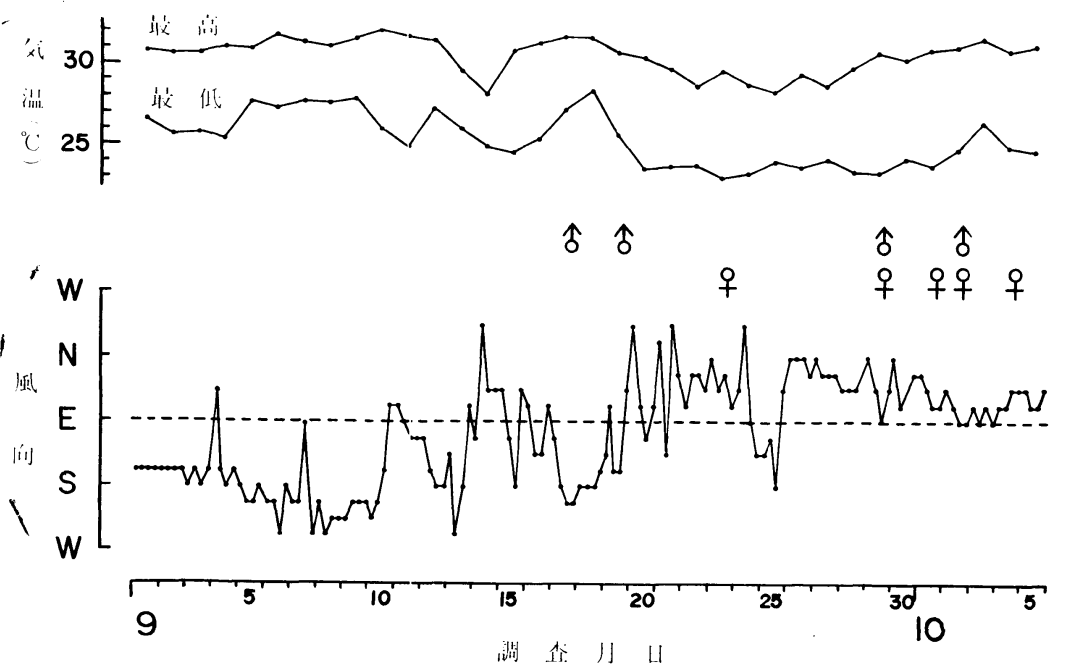

符 2 図 1973 年 9 月 1 日〜 10 月 5 日の日最问・最低気温および風向とタマナヤガ誘殺状況との関係. 気温は不垣島 (1973)，風向は石垣鼠地方気象台観測資料による.
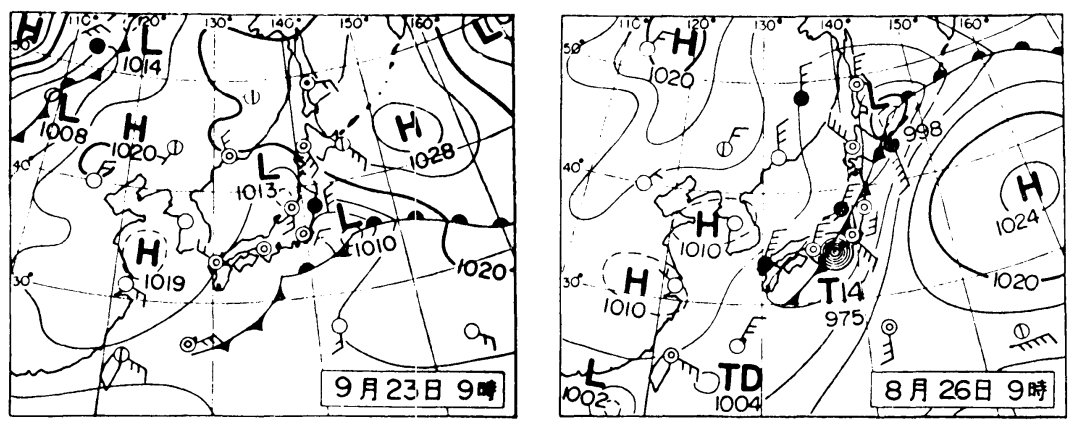

第 3 戝 秋の誘殺再開時の気圧配置の例. 天気図非記（1974，1975）による. 左：1973年 9 月23日，右：1974年 8 月26日.

AMS, 1925; RIVNEY, 1964; FAHMY et al., 1974)。石垣島 でも，盛夏には上記のように高温のため生息困難となるので, それ以前に成虫が生息可能な地域へ移動し去るのではないかと 考えられる。石垣島には標高 $200 \mathrm{~m}$ をこえる山地が多く, 最も 高い於茂登岳は $526 \mathrm{~m}$ であるが, 島が小さく, 地形に沿った海 風の吹き上げがあるので, 標高差による温度降下は, 一般にい われる $0.5 \sim 0.6^{\circ} \mathrm{C} / 100 \mathrm{~m}$ よりも少ないと考えられる。交た, 本種は休眠期を有しないので, 山上で越夏するとすれぼ, そこ で幼虫期を過ごさねばならないが，山地はほとんど原生林で幼 虫の食餌植物となるようなものはない。この 2 点から, 本種は 石垣島では山地で越夏する可能性はないと推測される。

中国大陸で $3 \sim 6$ 月に起こるアワヨトウ Pseudaletia separataの北への移動は, 南〜南西の風との関係が深いが (JoHNSON, 1969), この風は前述の温带低気圧による季節風であると 考えられる。東北地方で 4 〜 月に起こるタマナヤガの唀蛾灯 への飛来は, 温带低気圧が 日本海〜北海道方面を通過すること
と関係が深い (千葉, 1976; 布施，1977)。このことについて, 布施（1977） は飛来の経路を低気圧の経路と関係ゔけて推測し ているが，上記アワヨトウの例から，低気圧通過にともなう南 寄りの季節風に乗って飛来したとも考えられよう。石垣島でも 4 月〜 5 月に南寄りの風の出現率が高まるので (第 1 図), この 時期に前述の誘殺雌成虫の 卵巣発育個体率の低下が起ることと 考えあわせて, 島内で羽化した成虫がこの風に乗って北方へ飛 び去る可能性はあるものと考えられる。

石垣島における秋の誘殺再開状況の詳細を, 1973 年の場合に ついて第 2 図に示した。この年は 8 月下旬〜 9 月上旬には南 寄りの風が卓越していたが，9月 14 日ごろから北寄りの風が多 くなって気温も低下し，それとともに誘蛾灯への誘殺がみられ 始めた。天気図上でも 9 月 10 日ごろから大陸の寒気団の南下が 時々見られたが，下旬から 10 月上旬には南西諸島一帯が寒気団 の勢力下に入る気压配置（第３図左）が多くなった。1974 年に は 8 月下旬に早くも寒気団が南下し， 8 月 25 日〜 9 月 5 日の間 
は第３脳右に示したような気圧配置が多かった。この間，8月 28 日に初誘殺があり(雌雄各 1 頭)，9月 2 日までに雌 5 䫓，雄 3 䫓を数えた。このように秋の誘殺再開時期は年による早晚が あったが，両年とも寒気団の南下の始まりと一致していた。こ れらのことからすると，この時期に誘殺された成虫は，北寄り の風に乘ってこの島に飛来した温帯地域産のものだという想定 も成り立つ。なお，このことはアワヨトウの南への移動が 9 月 に起こる（JoHNSON，1969）のと時期的には大变よく類似して いる。

\section{引用文献}

CAYrol, R.A. (1972) "Entomologie appliqúee a l'agriculture" (A.S. BALAchowsky ed.) vol. II, Masson et Cie, Paris: $1255 \sim 1520$.

千葉武勝 (1972) 応動昆大会講演 (静阙).

千葉武勝 (1976) 北日本病虫研報 $27: 121$.

千葉武勝·長谷川 勉 (1971) 応動昆大会講演 (東宗).

千葉武勝 - 長谷川 勉 (1972) 北日本病虫研埌 $23: 66 \sim 70$.

FAHMY, H.S.M., M.H. Zazzou, A. A. M. Kamel and A. H. Elhemassy (1974) Bull. Soc. Entomol. Egypte $57:$ 153 164, 201 210.

布施 寞 (1975) 北日本病虫研報 $26: 77$.

布施 宽 (1977) 北日本病虫研報 $28: 108$.

長谷川 勉. 千葉武勝 (1969) 応動昆 13:124〜128.
石垣島（1973，1974，1975）気像庁月報, 日本気像協会, 東京. Johnson, C.G. (1969) Migration and Dispersal of Insects by Flight, Methuen Co., Ltd., London, 763 pp. KAPUR, A.P. (1955) Indian J. Ent. $17: 289 \sim 294$.

小林 尚 (1969) 東北農試研究速報 $10: 13 \sim 19$.

小林 尚 (1972) 農業技術 $27: 342 \sim 345$.

小林 尚·杉本 渥. 奥 俊夫 (1974) 昆虫学会講演 (盛菏).

倉嶋 厚 (1972) モンスーン一季節をはこぶ風, 河出書房新社,

東京 : $251 \mathrm{pp}$.

松浦博一 ·宮下和喜 (1977) 応動昆大会講演（東京).

Novák, I. and K. SpITZER(1972) J. Res. Lepid. 10:181 $\sim 184$.

OKU, T., O. SAITo and H. ABE (1975) Bull. Tohoku

Natl. Agric. Exp. Stn. $51: 51 \sim 59$.

尾崎幸三郎（1975）農林水産技術会議研究成果 $82: 170 p p$.

RAINEY, R.C. (1967) Israel J. Ent. 2: 187 189.

Rivney, E. (1964) Z. angew. Ent. 53:295 309.

滝口政数 (1960) 九州農業研究 $15: 90 \sim 92$.

天気図日記 $(1974 ， 1975)$ 気象年鑑，大藏省印刷局，東京：39, 36

Williams, C.B. (1925) Trans. R. entomol. Soc. London $\mathbf{7 1}:$ 439 456.

Woodhouse, E.J. and T.B. Fletcher (1912) Agric. J. India $7: 343 \sim 354$.

\section{南西諸島のヤノネカイガラムシ とその捕食性天敵 ${ }^{1}$}

\author{
中尾舜 一 \\ 久留米大学医学部生物学教室 \\ (1977 年 10 月 3 日)
}

カンキッの重要害虫の一つであるヤノネカイガラムシ Unaspis yanonensis (KUWANA) の日本における地理的分布は, 奥 代·是永 (1966), 奥代ら（1968）により詳細に 報告されてい る。しかし暖地では, 沖繩県 2 及び鹿児島県離島の, いわゆる南 西諸島に分布する正式の記録がないようである。筆者は, 数次 にわたる南西諸島のカンキッ害虫とその天敵の調査のさい, 奄 美大岛と德之島で本種の分布を確認した。また， その捕食性天 敵の観察をおこない，新しい天敵若干種を確認したので，ここ
に簡単に報告しておく。

なお, 奄美大島・德之島への本種侵入の歴史についてその経 験を提供され, 引用を快諾された栄 政文氏, 調査に協力され た牧野 晋氏, 天敵の種の同定をして頂いた佐々治寛之, 鮎沢 啓夫の両氏に対し衣心より感謝の意を表する。

調査結果と考察

\section{南西諸岛におけるヤノネカイガラムシの分布}

㫣美大島での本種の分布は, 現地ではすでに第 2 次大戦前か ら知られていた。この侵入の歴史については, 鹿児島農業試験 場大島支場元病害虫主任 栄 政交氏が記憶しておられる。同氏 の同意を得て, 以下にその概要を採録しておく。奄美大島への 最初の侵入は 1928〜1929 年で, ルビーロウカイガラムシと一 緒にわずかな発生が見られた。九州本土から移植したウンシュ ウミカンの苗木に附着して侵入したものと想像された。德之島 でも 1930 年に発生したことがある。この両島では, 被害樹を伐 採・焼却して全滅させた。戦後は, まず奄美大島住用村のポン

1 The Arrowhead Scale, Unaspis yanonensis, and its Predators in the Ryukyu Archiperago. By Shun-ichi NaKaO (Zoological Laboratory, School of Medicine, Kurume University, Kurume, Fukuoka 830)

日本応用動物昆虫学会誌 (応動昆) 第 22 巻 第 1 号 : 43〜 45 (1978)

2 古く桑名（1911）は沖繩県下に分布するとしているが，关の後分布の記録がなく，現地でも生息は知られていない， 